REPORTS OF MORPHOLOGY
$\begin{gathered}\text { Official Journal of the Scientific Society of Anatomists, } \\ \text { Histologists, Embryologists and Topographic Anatomists } \\ \text { of Ukraine } \\ \text { journal homepage: https://morphology-journal.com }\end{gathered}$

\title{
Histomorphometric assessment of changes in the acinus and islets of Lungerhans of the pancreas under conditions of general dehydration of the body
}

Kovchun V.Yu.

Sumy State University, Medical Institute, Department of Morphology, Sumy, Ukraine

\section{ARTICLE INFO}

Received: 15 March, 2018

Accepted: 17 April, 2018

UDC: $616.379-091.8-092.9: 616.395$

\section{CORRESPONDING AUTHOR}

e-mail: vu.kovchun@ukr.net Kovchun V.Yu.
Dehydration accompanies a number of pathological conditions and causes alteration of the organs and systems of an organism. Research aim: to study histomorphometric changes in pancreas under the conditions of general dehydration of an organism, to identify correlation between the studied groups. The experiment was carried out on 35 white male rats. Pancreas was stained with haematoxylin and eosin and also Van Gieson's stain was used. The size of acini and islets of Langerhans and other parenchyma formations were assessed. The acini area of has decreased by $6.5 \%$ $(p>0.05)$ in comparison with the intact group on the $3^{\text {rd }}$ day. The area of islets of Langerhans decreased by $2 \%(p>0.05)$ in comparison with the intact group. The area of islets of Langerhans has increased by $0.2 \%(p>0.05)$ on the $7^{\text {th }}$ dayof experiment in comparison with the control group and by $2.2 \%(p>0.05)$ in comparison with the $3^{\text {rd }}$ day. Acini area has increased by $7.2 \%(p>0.05)$ on the $7^{\text {th }}$ day in comparison with the control group and by $13.2 \%(p>0.05)$ in comparison with the $3^{\text {rd }}$ day. The acini area has increased by $25.8 \%(p<0.05)$ on the $10^{\text {th }}$ day in comparison with the control group; by $30.6 \%$ $(p<0.01)$ in comparison with the $3^{\text {rd }}$ day; by $20.2 \%(p>0.05)$ in comparison with the $7^{\text {rd }}$ day. The area of is lets of Langerhans has increased by $55.5 \%(p<0.001)$ incomparison with the control group, by $56.3 \%(p<0.001)$ in comparison with the $3^{\text {rd }}$ day; by $55.4 \%$ $(p<0.001)$ in comparison with the $7^{r d}$ day. The results analysis found the correlation between the area of islets of Langerhans and acini $r=0.407, p<0.05$; between the area of islets of Langerhans and dehydration degree $r=0.708, p<0.001$; between acini area and dehydration degree $r=0.534, p<0.001$. It was found by morphologically that the presence of destructive changes in the pancreatic parenchyma, which progress as the degree of severity of dehydration.

Keywords: pancreas, islets of Langerhans, acini, dehydration.

\section{Introduction}

Water is the basis of internal environment of an organism $[4,5,9,22,23]$. The violation of water-electrolytic balance accompanies a number of pathological conditions and causes alteration of the organs and systems of an organism $[7,10,21]$. WHO informs that about 1.5 million people die annually from dehydration in the world $[15,18]$. Understanding the vital role of water in a human body is the basis for comprehending the development mechanisms of pathological conditions [1, 2, 8, 25]. Endocrine system plays a key role in the system of water exchange control, providing an optimal volume of liquid in a body [14, 19]. All biochemical reactions, which occur in a human body and are associated with digestion, take place in the aquatic environment $[3,11$,
24]. Pancreas pathology takes the lead in the structure of morbidity, disability and mortality among Ukrainian population $[6,12,17,20]$. According to the research, the incidence of pancreas pathology is about 226 cases per 100.000 of Ukrainian population $[17,26]$.

Research aim: to carry out experimental research on mature laboratory rodents in order to identify histomorphometric changes in pancreas under the conditions of general dehydration of an organism and correlation of the studied groups.

\section{Materials and methods}

The experiment was carried out on 35 sexually mature 
white male rats, which were kept in inpatient conditions of vivarium. During the experiment, the experimental animals were kept in accordance with the regulations of European Convention for the Protection of Vertebrate Animals used for Experimental and Other Scientific Purposes (Strasbourg, 1986), the principles of the Declaration of Helsinki adopted by the General Assembly of World Medical Association (19642000) "General ethical rules of experiments on animals", approved by the National Congress of Bioethics (Kyiv, 2001).

The animals were divided into two batches: control (5 rats) and experimental (30 rats). The experimental batch was divided into 3 groups with 10 rats in each group depending on dehydration degree. After reaching the correspondent degree of dehydration, the animals were released from the experiment under anesthesia on the $3^{\text {rd }}$ day with mild dehydration, on the $7^{\text {th }}$ day with moderate dehydration and on the $10^{\text {th }}$ day severe dehydration.

For histological examination, pancreas was exposed by midline laparotomy and has been fixed in $10 \%$ neutral formalin solution for 24 hours. The experiment results were entered in the sample protocol. The passing of microtome knife and manufacture of paraffin blocks were carried out according to the established procedure $[13,16]$.

The sledge microtome MC-2 was used to produce paraffin serial sections of acini center with the thickness of 5-9 microns, they were stained with Haematoxylin and Eosin and also Van Gieson's stain was used. The obtained preparations were studied and photographed with the help of image viewing system "SEO Scan Lab 2.0" (Ukraine). The size of acini and islets of Langerhans, the structure of endocrine cells and other gland parenchyma formations and gland stroma were assessed. The results of morphometric measurements were processed using the statistical methods and the statistical software IBM SPSS Statistic 21. The identification of differences probability between the mean values of several groups was performed using One-Way ANOVA together with F-test and Bonferroni correction. As a correlation coefficient between the values of the interval scale, the Pearson correlation coefficient was used.

\section{Results}

The average area of acini and islets of Langerhans are shown in Table 1.

While studying the pancreas histostructure of the control series, it was microscopically determined that the gland is represented predominantly by the exocrine tissue - cone shaped acini, apical parts are turned into secretory duct from which the insertion sections of the pancreatic duct originate. The average acini size was $983.4 \pm 63.5$ microns. In the acinous parenchyma, there were endocrine cells, islets of Langerhans of various shapes and sizes, sharply separated from the exocrine cells by a thin layer of connective tissue, consisting of collagen, reticular and elastic fibers. There are cells which are firmly against each other in the center of the islets. These are $\beta$-cells of oval, sometimes round shape with light cytoplasm. There is an insignificant amount of $\alpha$ - and D-cells on the periphery of an islet, which are smaller in size. The average size of islets of Langerhans was $13934 \pm 688$ microns.

Under the conditions of general dehydration in pancreas parenchyma of laboratory rodents, the structural changes occurred in all experimental groups. On the $3^{\text {rd }}$ day of study, histological structure showed that the exocrine part of pancreas retains its lobulation. The center acinous cells are of irregular cone shape, the oval nucleus is located on the basal pole. There are some binucleate acinar cells. Loose fibrous connective tissue appears around the vessels. Capillaries and arterioles are somewhat enlarged with the signs of moderate edema of the endothelium without signs of haemorheologic disorders (Fig. 1).

The acini area of has decreased by $6.5 \%(p>0.05)$ in comparison with the intact group on the $3^{\text {rd }}$ day. The area of islets of Langerhans decreased by $2 \%(p>0.05)$ in comparison with the intact group.

The $7^{\text {th }}$ day of experiment has shown the growth of connective tissue fibers around the vessels. Haemocapillaries are significantly enlarged, venules are dilated, arterioles lumen is uneven. There are single infiltrates around the vessels represented mainly by lymphocytes and macrophages. The excretory duct are with singular leukocytic infiltrates and inhomogenous secretion in their lumen (Fig. 2).

The area of islets of Langerhans on the $7^{\text {th }}$ day has increased by $0.2 \%(p>0.05)$ in comparison with the control

Table 1. The average area of acini and islets of Langerhans.

\begin{tabular}{|c|c|c|c|c|c|c|c|c|c|c|c|}
\hline $\begin{array}{c}\text { Experimental } \\
\text { series }\end{array}$ & $\begin{array}{c}\text { group/condition } \\
(\mathrm{n}=5)\end{array}$ & $\begin{array}{c}1 \text { group, mild } \\
\text { dehyration } \\
(\mathrm{n}=10)\end{array}$ & $\begin{array}{c}2 \text { group, } \\
\text { moderate } \\
\text { dehydration } \\
(\mathrm{n}=10)\end{array}$ & $\begin{array}{c}3 \text { group, } \\
\text { severe } \\
\text { dehydration } \\
(\mathrm{n}=10)\end{array}$ & $\mathrm{P}_{0}$ & $\mathrm{P}_{1}$ & $\mathrm{P}_{2}$ & $\mathrm{P}_{3}$ & $\mathrm{P}_{4}$ & $\mathrm{P}_{5}$ & $\mathbf{F}$ \\
\hline $\begin{array}{c}\text { S of islets of } \\
\text { Langerhans, } \\
\text { microns }\end{array}$ & $13934 \pm 688$ & $1365 \pm 1434$ & $13960 \pm 1571$ & $31281 \pm 2858$ & $>0.05$ & $>0.05$ & $<0.01$ & $>0.05$ & $<0.01$ & $<0.01$ & 23.78 \\
\hline $\begin{array}{c}\text { S of acini, } \\
\text { microns }\end{array}$ & $983.4 \pm 63.5$ & $920.2 \pm 121.3$ & $1059 \pm 63$ & $1326 \pm 70$ & $>0.05$ & $>0.05$ & $<0.05$ & $>0.05$ & $<0.01$ & $>0.05$ & 4.600 \\
\hline
\end{tabular}

Note: $P_{0}$ - statistical significance of differences between groups 0 and $1 ; P_{1}$ - statistical significance of differences between groups 0 and 2; $P_{2}$ - statistical significance of differences between groups 0 and $3 ; P_{3}$ - statistical significance of differences between groups 1 and $2 ; \mathrm{P}_{4}$ - statistical significance of differences between groups 1 and $3 ; \mathrm{P}_{5}$ - statistical significance of differences between groups 2 and 3 . 


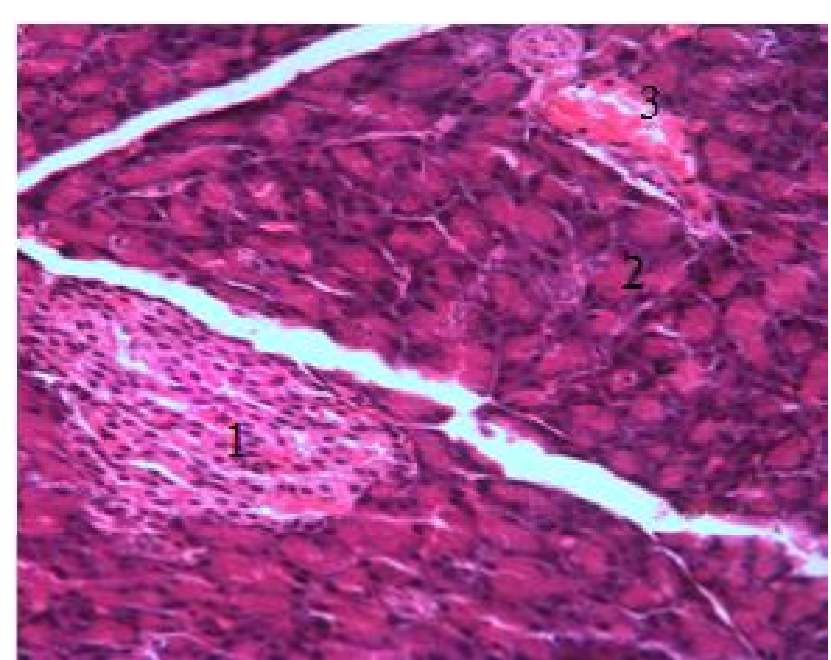

Fig. 1. Pancreas of a rat. General dehydration. $3^{\text {rd }}$ day. Anislet of Langerhans, lobulation of pancreas parenchyma is preserved. 1 Anislet of Langerhans, 2 - pancreatic acinus, 3 - blood vessel. Haematoxylin and eosin stain. x200.

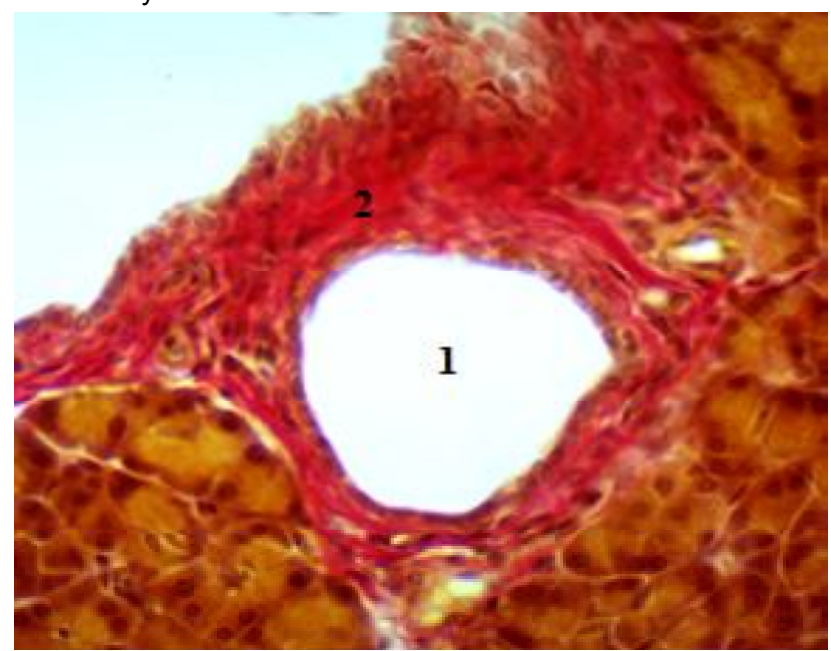

Fig. 2. Pancreas of a rat. Exocrine part. General dehydration. $7^{\text {th }}$ day. Advanced fibrosis around the ducts and epithelium desquamationin the ducts. 1 - withdrawal duct, 2 - edema, wall fibrosis. Van Gieson's stain. x400.

group and by $2.2 \%(p>0.05)$ in comparison with the $3^{\text {rd }}$ day. Acini area on the $7^{\text {th }}$ day has increased by $7.2 \%(p>0.05)$ in comparison with the control group and by $13.2 \%(p>0.05)$ in comparison with the $3^{\text {rd }}$ day.

The 10th day of the study demonstrated the significant structural changes in the exocrine and endocrine part of pancreas parenchyma. The gland structure when stained with haematoxylin and eosin and using Van Gieson's stain preserve lobulation, but most of the acini lose sharp contours due to swelling of the connective tissue. There is epithelium desquamation, advanced fibrosis around the excretory ducts. There are some areas of focal angiomatosis. There are perivascular leukocytic infiltrations and edema (Fig. 3).

Islets of Langerhans are of irregular shape, large in size due to hydropic dystrophic changes. There is lesser quantity of $\beta$-cells located in the islet center, the nuclei of the latter are of high density, hyperchromatic, between which the connective tissue is diagnosed due to edema (Fig. 4).

The area of islets of Langerhans has increased by $55.5 \%(p<0.001)$ in comparison with the control group, by $56.3 \%(p<0.001)$ in comparison with the $3^{\text {rd }}$ day; by $55.4 \%$ $(p<0.001)$ in comparison with the $7^{\text {th }}$ day. The acini area has increased by $25.8 \%(p<0.05)$ on the 10 th day in comparison with the control group; by $30.6 \%(p<0.01)$ in comparison with the $3^{\text {rd }}$ day; by $20.2 \%(p>0.05)$ in comparison with the $7^{\text {th }}$ day.

The results analysis found the correlation between the area of islets of Langerhans and acini $r=0.407, p<0.05$; between the area of islets of Langerhans and dehydration degree $r=0.708, p<0.001$; between acini area and dehydration degree $r=0.534, p<0.001$.

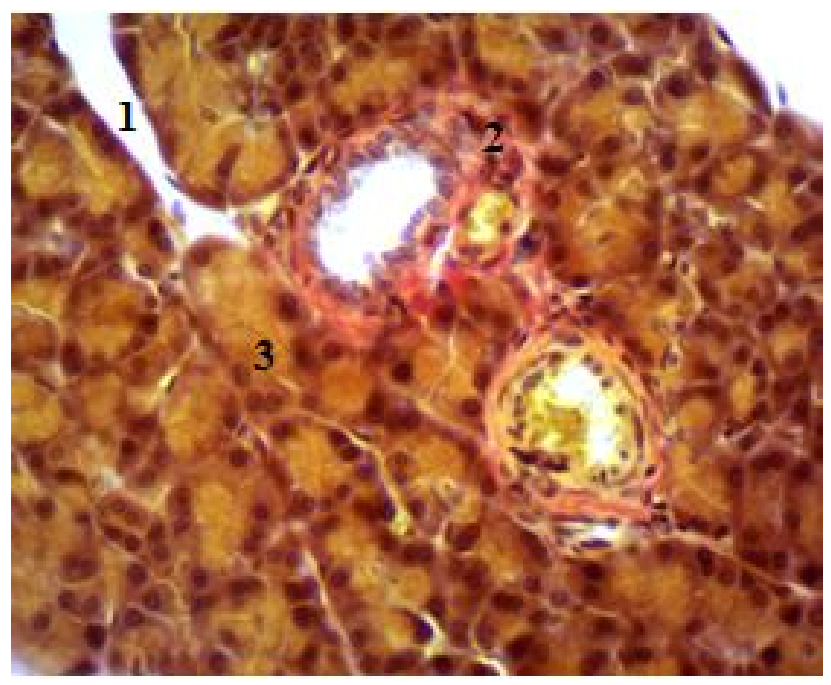

Fig. 3. Pancreas of a rat. Exocrine part. General dehydration. $10^{\text {th }}$ day. Stromal edema, enlargement of the connective tissue around the vessels and heterogeneity of the secretion in the ducts. 1 interacinic edema, 2 - lymphohistocytic infiltration, 3 - pancreatic acinus. Van Gieson's stain. x400.

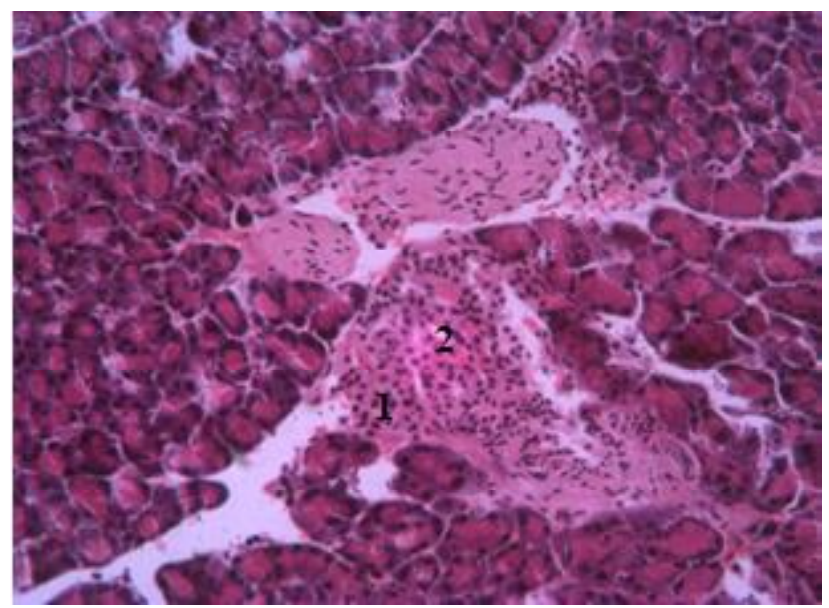

Fig. 4. Pancreas of a rat. Exocrine part. General dehydration. $10^{\text {th }}$ day. Islet deformation, lesser quantity of $\beta$-cells located in the islet center. 1 - $\alpha$-cells, 2 - $\beta$-cells. Hematoxylin and eosin stain. x200. 


\section{Discussion}

In the conditions of general dehydration, changes in the histostructure of the parenchyma were found in all experimental series. The severity of the destructive changes in the exo- and endocrine parenchyma and microcirculatory bloodstream is progressing as the degree of severity of dehydration increases [4]. There is a large amount of data on the effect of various exogenous factors on the parenchyma of the pancreas in the literature, special attention is paid to the effects of alcohol and narcotic substances [1,3]. The authors note the expression of degenerative changes in glandular cells and proliferation of connective tissue, obliteration and the phenomenon of endarteritis are observed in the vessels. In the excretory ducts, periductal fibrosis and epithelial proliferation are detected. Scientists have noted a decrease in the islets of Langerhans due to their wrinkling. A significant amount of work is devoted to the study of the effect of nicotine, in which the authors note the edema of cells and the compaction of nuclei with cell pycnosis. Taking into account a small number of studies in which the authors studied the effect of dehydration on the pancreatic parenchyma and their contradictory nature, we decided to conduct research

\section{References}

[1] Abd El-Haleem, M. R., \& Mohamed, D. A. (2011). The effects of experimental aflatoxicosis on the pancreas of adult male albino rats and the role of ginger supplementation: a histological and biochemical study. The Egyptian Journal of Histology, 34, 423-435.

[2] Alipov, N. N. (2013). Fundamentals of Medical Physiology. 2nd ed. M.: Practice. ISBN: 978-5-89816-122-4

[3] Ayuob, N., \& El Beshbeishy, R. (2016). Impact of an energy drink on the structure of stomach and pancreas of albino rat: can Omega-3 provide a protection? PLoS One, 11(2): e0149191. doi: 10.1371/journal.pone.0149191.

[4] Cho, I.-J., Chang, H.-J., Sung, J. M., Yun, Y. M., Kim, H. C., \& Chung, N. (2017). Associations of changes in body mass index with all-cause and cardiovascular mortality in healthy middle-aged adults. PLoS One, 12(12): e0189180. doi: [10.1371/journal.pone.0189180]

[5] Chowdhury, A. H., \& Lobo, D. N.(2011). Fluids and gastrointestinal function. Curr. Opin. Clin. Nutr. Metab. Care., 14(5), 469-476. doi:10.1097/MCO.0b013e328348c084

[6] Chowdhury, P., \& Udupa, K. B. (2013). Effect of nicotine on exocytotic pancreatic secretory response: Role of calcium signaling. Tob. Induc. Dis., 11(1). doi: 10.1186/1617-9625-11-1.

[7] Dergunov, A. V., Khmara, V. M., \& Gusev, G. P. (2012). Disorders of electrolyte metabolism in tissues of rats with dehydration and hyperhydration. Actual Issues of Transport Medicine, 28(2), 139-143.

[8] Gandi, J. (2015). Water intake: validity of population assessment and recommendations. Eur. J. Nutr. 54(2), 11-16. doi:10.1007/ s00394-015-0944-8

[9] Goncharuk, V. V. (2013). Water is the planet's global buffer and its immune system. Water - hygiene and ecology, 1(1), 8-20.

[10] Gula, V. I., Prikhodko, O. O., Bumeister, V. I., Yarmolenko, O. S., \& Bolotna, I. V. (2013). Modern view on the problem of dehydration disorders of the body. Bukovinsky Medical Bulletin, 20(2), 78, 186-190. in this direction.

The prospects for further research suppose the changes study in pancreas parenchyma under the conditions of intracellular dehydration.

\section{Conclusions}

1. The analysis of pancreas morphometric data under the conditions of general dehydration showed that the histostructure of gland parenchyma undergoes changes in all experimental groups. The morphological structure proved that destructive changes in both the exocrine and endocrine parenchyma and the microcirculatory bloodstream progress with the severity degree of dehydration.

2. The significant increase in acini area and islets of Langerhans occurs under the condition of severe dehydration. The results comparison of mild and moderate dehydration in comparison with the control group has not shown significant differences. One can suppose that it was caused by adaptive-compensatory mechanisms.

3. A direct connection is established between dehydration degree and the area of acini and islets of Langerhans.

[11] Hooper, L., Bunn, D., Jimoh, F. O., \& Fairweather-Tait, S. J. (2014). Water-loss dehydration and aging. Mech Ageing Dev., 136-137, 50-8. doi: 10.1016/j.mad.2013.11.009.

[12] Kiptenko, L. I., Vasko, L. V., \& Hortitskaya, O. M. (2013). Morphological changes of the internal organs of rats in conditions of cellular dehydration on the background of posttraumatic regeneration of the tibia. World of Medicine and Biology, 2(38), 41-43.

[13] Lilly, R. (1969). Histopathological technique and practical histochemistry. Manual: [Trans. from English]. M.: Mir.

[14] Maisa, M. A. Al-Qudah, Moawiya, A. Haddad, \& Jafar, M. F. ELQudah. (2016). The effects of aqueous ginger extract on pancreas histology and on blood glucose in normal and alloxan monohydrate-induced diabetic rats. Biomedical Research, 27(2), 350-356.

[15] Mahon, E., Hackett, T., Stott, T., \& Devies, L. (2014). An assessment of the hydration status of recreational endurance athletes during mountain marathon events. American J. of Sports Science, 2(4), 77-86. doi: 10.11648/j.ajss.20140201.12

[16] Microscopic technique: Manual for physicians and laboratory technicians. (1996). Ed. D. S. Sarkisov, \& Yu. L. Perova. M.: Medicine.

[17] Mokienko, A. V., Gozhenko, A. I., \& Petrenko, N. F. (2012). Chlorination of water: decontamination or adaptation, inactivation or stimulation? Bulletin of the National Academy of Sciences of Ukraine, 11, 32-40.

[18] Netyukhaylo, L. G., Filatova, V. L., \& Filatov, O. V. (2012). Water-salt metabolism (review of literature). Bulletin of Biology and Medicine, 91(1), 28-33.

[19] Nortje, C. J. \& Harris, A. M. (2001). Endocrine mechanism texty in the developing rat chronically exposed to dietary lead. Front. Neuroendocrinology, 56(11), 502-514.

[20] Order of the Ministry of Health of Ukraine from 10.09.2014 №638 "Unified clinical protocol for primary, secondary medical care and medical rehabilitation. Chronic pancreatitis". 
[21] Poputnikov, D. M., Melenchuk, E. V., \& Wismont, F. I. (2011). Disorders of water-electrolyte metabolism (pathophysiological aspects). Minsk: BHMU.

[22] Rusnak, I. T. Tashchuk, V. K., Ibragimova, S. Yu., \& Semenov, P. V. (2013). Clinical case of latent dehydration. Young Scientist, 1(1), 103-106.

[23] Rusnak, I. T., Tashchuk, V. K., Ibragimov, E. Yu., \& Skoropadsky, V. V. (2013). The role of water in the human body, the risks of dehydration. Young Scientist, 1(1), 107-110.

[24] Shimoda, M., Kanda, Y., Hamamoto, S., Tawaramoto, K., Hashiramoto, M., Matsuki, M., \& Kaku, K. (2011). The human glucagon-like peptide-1 analogue liraglutide preserves pancreatic beta cells via regulation of cell kinetics and suppression of oxidative and endoplasmic reticulum stress in a mouse model of diabetes. Diabetologia. 54(5), 1098-1108. doi: 10.1007/s00125-011-2069-9.

[25] WHO recommendations on the management of diarrhea and pneumonia in children. - World Health Organisation, 2014.

[26] Yang, H., Wang, L., Shi, Y. H., Sui, G. T., Wu, Y. F., Lu, X. Q.... Li, H. H. (2014). Risk factors of acute pancreatitis in the elderly Chinese population: A population-based cross-sectional study. J. Dig. Dis., 15, 501-507. doi: 10.1111/1751-2980.12168.

\section{ГІСТОМОРФОМЕТРИЧНА ОЦІНКА ЗМІН АЦИНУСІВ ТА ОСТРІВЦІВ ЛАНГЕРГАНСА ПІДШЛУНКОВОЇ ЗАЛОЗИ ЗА УМОВ ЗАГАЛЬНОГО ЗНЕВОДНЕННЯ ОРГАНІЗМУ \\ Ковчун В.Ю.}

Зневоднення супроводжує ряд патологічних станів і викликає перебудову органів і систем організму. Мета дослідження: дослідити гістоморфометричні зміни підшлункової залози за умов загального зневоднення організму. Встановити кореляційні зв'язки між досліджуваними групами. Дослід був проведений на 35 білих щурах-самцях. Підшлункову залозу забарвлювали гематоксилін-еозином та за Ван-Гізон. Оцінювали розміри ацинусів, острівців Лангерганса та інші утворення паренхіми. Площа ацинусів на 3 добу відносно інтактної групи зменшилася на 6,5\% (p>0,05). Площа острівців зменшилася на $2 \%$ $(p>0,05)$ відносно інтактної групи. На 7 добу експерименту площа острівців збільшилася на 0,2\% $(p>0,05)$ відносно групи контролю; на 2,2\% (p>0,05) відносно 3 доби. Площа ацинусів на 7 добу збільшилася на $7,2 \%(p>0,05)$ відносно групи контролю та на 13,2\% $(p>0,05)$ відносно 3 доби. Площа ацинусів на 10 добу збільшилася на 25,8\% $(p<0,05)$ відносно групи контролю; відносно 3 доби на 30,6\% ( $p<0,01)$; відносно 7 доби на 20,2\% ( $p>0,05)$. Площа острівців збільшилася на 55,5\% ( $p<0,001)$ відносно групи контролю; відносно 3 доби на 56,3\% (p<0,001); відносно 7 доби на 55,4\% ( $p<0,001)$. Встановлено наявність кореляційного зв'язку між площею острівців та ацинусів $r=0,407, p<0,05$. Між площею острівців та ступенем зневоднення $r=0,708, p<0,001$; між площею ацинусів та ступенем зневоднення $r=0,534, p<0,001$. Морфологічно встановлено наявність деструктивних змін паренхіми підшлункової залози, що прогресують за мірою зростання ступеня тяжкості дегідратації. Ключові слова: підшлункова залоза, острівці Лангерганса, ацинуси, зневоднення.

\section{ГИСТОМОРФОМЕТРИЧЕСКАЯ ОЦЕНКА ИЗМЕНЕНИЙ АЦИНУСОВ И ОСТРОВКОВ ЛАНГЕРГАНСА ПОДЖЕЛУДОЧНОЙ ЖЕЛЕЗЫ В УСЛОВИЯХ ОБЩЕГО ОБЕЗВОЖИВАНИЯ ОРГАНИЗМА \\ Ковчун В.Ю.}

Обезвоживание сопровождает ряд патологических состояний и вызывают перестройку органов и систем организма. Цель исследования: исследовать гистоморфометрические изменения поджелудочной железы в условиях общего обезвоживания организма. Установить корреляционные связи между исследуемыми группами. Опыт был проведен на 35 белых крысах-самцах. Поджелудочную железу окрашивали гематоксилин-эозином и по Ван-Гизон. Оценивали размеры ацинусов и островков Лангерганса и другие образования паренхимы. Площадь ацинусов на 3 сутки относительно интактной группы уменьшилась на 6,5\% (p>0,05). Площадь островков уменьшилась на $2 \%(p>0,05)$ относительно интактной группы. На 7 сутки эксперимента площадь островков увеличилась на 0,2\% (p>0,05) относительно группы контроля; на 2,2\% $(p>0,05)$ относительно 3 суток. Площадь ацинусов на 7 сутки увеличилась на 7,2\% (p>0,05) относительно группы контроля и на 13,2\% (p>0,05) относительно 3 суток. Площадь ацинусов на 10 сутки увеличилась на 25,8\% ( $p<0,05)$ относительно группы контроля; относительно 3 суток на 30,6\% (p<0,01) в отношении 7 суток на 20,2\% (p>0,05). Площадь островков увеличилась на $55,5 \%(p<0,001)$ относительно группы контроля; относительно 3 суток на $56,3 \%(p<0,001) ;$ в отношении 7 суток на 55,4\% $(p<0,001)$. Установлено наличие корреляционной связи между площадью островков и ацинусов $r=0,407$, $p<0,05$. Между площадью островков и степенью обезвоживания $r=0,708, p<0,001$; между площадью ацинусов и степенью обезвоживания $r=0,534, p<0,001$. Морфологически установлено наличие деструктивных изменений паренхимы поджелудочной железы, которые прогрессируют по мере роста степени тяжести дегидратации.

Ключевые слова: поджелудочная железа, островки Лангерганса, ацинусы, обезвоживание. 